In manner modest and in disposition equable, he won, by his qualities of character as much as by his knowledge and judgment, the respect and confidence not only of those who like himself were concerned with representing the interests of employers but also of the senior officials of the many Government departments and trade unions with which he came into contact. His unvarying kindliness gained for him a wide circle of friends throughout industry and in the public service who will remember him with affection.

KENNETH J. BURTON

\title{
SIR CHARLES FREDERICK TRUSTAM
}

Charles Frederick Trustam died on 10 January 1964 after a short illness.

Born in 1900, he was educated at Hymers College, Hull, and Trinity College, Cambridge, where he graduated as a Wrangler in 1921. Duncan C. Fraser, who was then Actuary of the Royal, knew his tutor at Cambridge and recruited Trustam to the actuarial staff of his Company in I iverpool. Trustam qualified for the Fellowship of the Institute in 1925.

In 1929 he was appointed Assistant London Secretary of the Royal and began the series of rapid strides that took him to the top post in his companies and to a position of leadership in British insurance. Three years later he became Assistant London Manager and in 1936 a Sub-Manager at the Company's head office in Liverpool. Appointed a General Manager in 1944, he became the chief executive of the Royal Group in 1952 and retired on 31 December 1962 with the title of Chief General Manager.

He was President of the Chartered Insurance Institute in 1953 and Chairman of the British Insurance Association from 1957 to 1959. At New Year 1960 he received the honour of Knighthood.

As a young man, Trustam took an active part in the affairs of the Institute and his contributions usually had a mathematical flavour. For his paper in 1927 On a New Method of Calculating Model Office Reserves (J.I.A.58, 195) he received an award from the Messenger and Brown Prize Fund. He served the Institute successively as a tutor, examiner and honorary librarian. Growing responsibility in general management left him little time for professional work but he continued to serve on the administrative side of the Institute as a member of Council during the period between 1935 and 1955 and as a VicePresident from 1952 to 1954.

Trustam married in 1926 and is survived by his widow and two daughters. Outside home and business his chief interest lay in the theatre and in 1952 he joined the board of the Liverpool Playhouse, the oldest repertory theatre in the country, later becoming Chairman. He moved to London in 1960 when the Royal group of companies formed a chief administration there and continued his interest in the theatre by becoming a director of the proposed Yvonne Arnaud Memorial Theatre at Guildford. For some time he was a member of the Court of the University of Liverpool and a member of the Appointments Board of the University of Cambridge. Recently he was appointed to the three-man Location of Offices Bureau.

Trustam combined outstanding intellectual powers with a quiet and unassuming manner. He had apparently weathered the mental and physical strains of extensive travel at home and overseas and of the many exacting positions he had filled. It was therefore a shock to learn so soon after his retirement that he was afflicted with a fatal illness. His death came just over 12 months after the close of a career during which he had been a leading figure in the British insurance industry.

J. M. B E A T TIE 